\title{
Tasarım Sürecinde Eskiz ile Biçim-İçerik Sorgulama ve Çözümlemeleri: Bir Durum Analizi
}

\author{
Arş. Gör. Barış Yakın
}

\section{Öz}

Çalışma, eskiz çizimlerinin tasarım süreci boyunca gerçekleştirilen sorgulama ve çözümleme eylemlerine katkısını araştırır. Süreçte tasarımcının düşünsel bir aktivite olarak başvurduğu eskiz çizimlerinin, zihin-göz-el-imge ilişkisi sonucu dışa vurumu ve hedef olan tasarım bilgisinin oluşumu/gelişimi incelenmiştir. Tasarım bilgisinin oluşum ve gelişim sürecinde eskiz çalışmaları ile anlamsal, işlevsel ve biçimsel verilerin hangi sistematikte işlemlendiği ve bu işlemlerin sonucunda birbirleri arasındaki veri paylaşımı araştırılmıştır. Belirlenen sistematikte Libeskind'in Berlin Yahudi Müzesine dair eskiz çalışmaları, durum analizi yöntemiyle değerlendirilmiştir. Zihin-göz-el-imge arasında gerçekleşen döngüsel ilişki ile ortaya çıkan eskizler, biçim-içerik özelliklerine göre analiz edilmiştir.

Anahtar Kelimeler: Eskiz, Tasarım Süreci, Libeskind

\section{ANALYZING FORM-CONTEXT THROUGH SKETCHES IN DESIGN PROCESS: A CASE STUDY}

\begin{abstract}
This study questions the contribution of sketch drawings as an analyze action in the design process. As a result of the relation between the mind, the eye, the hand and the image sketch drawings' -which is a thinking act- aim is to generate design data. The systematic of design data which contain semantic, functional and formal qualities has been analyzes. Using case-study, this paper evaluates Libeskind's Jewish Museum Berlin's sketch drawings. Sketches which are the results of the cyclic reslation between the mind, the eye, the hand and the image are analyzed by their form-context specs.
\end{abstract}

Keywords: Sketch, Design Process, Libeskind 
Tasarım alanlarında eskiz çizimleri, yeni tasarım bilgisi ve tasarım düşüncesi türetme eylemlerinin gerçekleşmesinde bir aktarım aracından fazlasıdır. Tasarlama sürecinde, tasarımcının düşünme, aktarma ve bilgi türetme eylemlerini zihinde kurguladığından öteye taşır. Goldschmidt (1994), tasarımcının eskiz çizimini yaptığı veya bitirdiği sırada, başlangıçta planlamadığı bir takım yeni bilgilerin tasarımcıya iletildiğini açıklamıştır. Bu iletimler, zihin-göz-el-imge dörtlüsü arasındaki döngüsel ve sürekli iletişim sistemini oluşturan ve tasarımdaki yeniyi ortaya çıkaran paylaşımlardır.

Pallasmaa (2009: 37), imgenin, zihinde ve elin ürettiği eskizlerde eşzamanlı oluştuğunu savunmuştur. Kâğıttaki çizginin mi yoksa zihindeki düşüncenin mi önce oluştuğunu bilmenin imkânsız olduğundan bahseder ve bir bakıma imgenin el aracılığıyla kendiliğinden oluştuğunu iddia etmiştir.

Sözü edilen eşzamanlı sistematik, döngüsel-sürekli bir sistematiği işaret eder. Steadman (1972: 26), Akin (1990) ve Lawson'a (1990: 45) göre yeni verilerin ortaya çıkışında ve karşıııklı paylaşımlarda bir sıra(lama) bulunmamaktadır. Bu sırasız, sürekli döngü; çizimler aracılığıyla veya çizimlerin kendine sorulan sorular ve bunlara getirilen çözümlemelerin bütünü olarak ortaya çıkmışır. Kant'a göre düşünmek; yargılamaktır, Aristoteles'e göre yargılamak ise; doğruluk ve yanlışlığın bulunması ile ortaya çıkan önermeler olduğunu savunmuştur. Brooker ve Stone (2011: 23), tasarım sürecinin temelinin, mevcut durumun sorgulanması ve bu sorgulara birer cevap bulunması olduğunu ileri sürmüştür. Özetle tasarımcının eskiz ile ilişkisi yani zihin-göz-el-imge arasında gerçekleşen paylaşım bir sorgulama ve çözümleme eylemidir. Bu eylem, bütüncül tasarlama sürecinde ve her bir aşamasında başvurulacak en temel harekettir.

Gero (1999)'ya göre, yeni tasarım bilgisi üretmek amaçlı en eski ve kabul görmüş aşamalar Asimov'un ortaya attıklarıdır. Bunlar:

\section{- Analiz}

\section{- Sentez}

\section{- Değerlendirmedir.}

Analiz, sentez ve değerlendirme aşamaları eskiz çalışmalarının sorgulamaçözümleme temelini oluşturur. Herhangi bir ihtiyaç veya probleme yanit verecek tasarlama aktivitelerinde sorgulama ve çözümleme işlemlerini alanlarına göre detaylandırmak gerekir. Bu bağlamda İnceoğlu (2012: 44), düşünceye yönelik eskizler kullanarak çözümleme yaklaşımları ile ana fikir yaratmayı; bağlamcı, sembolik ve kavramsal başlıklarıyla örneklemiştir. 
- Bağlamcı yaklaşımla tasarımcının, ürünün çevreyle olan ilişkilerini ve uyumluluğunu değerlendirir.

- Sembolik değerler üzerine kurulan çözümleme temeli bir diğer yaklaşım olarak göze çarpar.

- Kavramsal yaklaşımda ise soyut verilerden yola çıkılarak bir çözümleme yolu izlenir.

Bağlamcı; pragmatik ve işlevci, sembolik ve kavramsal yaklaşımlar; düşünsel tasarım verilerini ortaya çıkarmakta görev alabilmektedir. Bu içeriğe dair bilgilerin bir "tasarımı" oluşturabilmesi için ise somut bir biçime aktarılması gerekmektedir. Daha kapsayıcı bir temelde ele alınacak olursa; sorgulama ve çözümleme eylemleri;

- İçerik sorgulama - çözümlemeleri

- Anlamsal sorgulama-çözümlemeler

- İşlevsel sorgulama-çözümlemeler

- Biçim sorgulama - çözümlemeleri olarak iki başlıkta incelenebilir.

Bu başlıklar altında yapılacak sorgulama ve çözümleme işlemleri, tasarlanan ürünün ne anlattığı, ne işe yaradığı, nasıl kullanıldığı, nasıl duyumsandığı kısaca neden böyle sonuçlandığının kararlarının alınmasını sağlamaktadır. Özetle, tasarımcı ve eskiz çizimlerinin iletişimi ile ihtiyaç veya problemin genelinden detayına kadar kullanılabilecek tasarım kararları yaratılmaktadır.

Tasarımcı-eskiz çizimi ilişkisinin sürekli ve döngüsel ilişkisi anlam, işlev ve biçimleniş yaklaşımları türetme eylemlerini kapsadığı için bu aşamalarda da geçerlidir. Anlam-işlev-biçim, zihinde ve eskizlerde her an iletişim kurmakta ve gelişmektedir. Bu geliştirme süreci elbette duyuşsal ve bilişsel altyapıya ve birikimlere başvurularak gerçekleştirilir. Bunlar anlamı, işlevi ve biçimi besleyecek verilerdir.

Sözü geçen eskiz-tasarımcı arasındaki sorgulama ve çözümleme ilişkileri Daniel Libeskind'in 1999 tarihli Berlin Yahudi Müzesi projesi üzerinde okunmuştur. Mimarın duyuşsal-bilişsel birikimlerinin eskizle ve/veya eskiz aracılığıyla, döngüsel ve sürekli gelişim aşamaları analiz edilmiştir. Duyuşsal ve bilişsel birikimlerinde; mimarın röportajları, metinleri, geçmiş çalışmalarından yararlanılmış, bu bilgilerin projeye ait eskiz çizimlerinde ne tür anlamsal-işlevsel-biçimsel verilere dönüştüğü araştırılmıştır. 
Gerçekleştirilecek analizlerde tasarımcının eskizleriyle iletişiminde diyagramlara başvurulmuştur. Diyagramların çalışma sistematiği döngüsel -sürekli geri beslemeli- kurgularda çalışmaktadır.

Eskiz analizinde kullanılmaküzere, mimarın Berlin Yahudi Müzesi projesinde tasarım bilgisi olarak kullandığı duyuşsal-bilişsel birikimleri incelenmiştir. Mimarın geçmişine ait bilgiler; eskiz çalışmalarında gerçekleşen sorgulama ve çözümleme eylemleri ile türevlerini yaratmış ve sonuç üründe yani mimari yapıda somutlaşmıştır.

Laseau (2001: 8)'ya göre, tasarımda "yeni" fikirler, eski fikirlere yeni bir bakışla ve bu eski fikirler arasında yeni bağlantılar kurmakla yaratılmaktadır. İnsanın düşünme süreci, fikirleri yeniden düzenlemekte, bazı kısımlara odaklanmakta ve kurgulamaktadır.

- Micromegas: Libeskind'in kullandığı bu kaotik kompozisyonların ortaya çıkışı 1979 yılında gerçekleştirdiği Micromegas adlı -ismini Voltaire'in, Micromegas öyküsünden almıştır- soyut, iki boyutlu çalışmaları ile ilk kez kamusallaşmıştır. Bu çalışmalar, zamansız, strüktürsüz, anlamsız, işlevsiz(!) biçimsel görsel anlatımlardır.

Alois Martin Müller'in, Micromegas ile ilgili metninde (Libeskind, 1991: 67), mimarın bu çizimleri; geleneksel düzen, yapısal geometrik özellikler, arazi incelemesi ve uzamsal boyutluluk verilerinin tersi bir anlayışta gerçekleştiğinden bahsetmiştir. Geometri, atomlarına ayrılmış ve bir "hiçmekan" üretilmiştir.

Young (2000), Libeskind'in Micromegas çalışmalarında, biçimin işlevi oluşturmaktan çok daha öte bir görevi olabileceğini ve bu görevi de en az elemanla ifade edebileceğini kanıtlamak istediğini savunmuştur.

Eisenman, Micromegas ile ilgili metninde (Libeskind, 1991: 102), bilgi paylaşıcı mimari çizimlere bir eleştiri olduğunu ve mimarlık-dışı parçalayıcı çalışmalar olduğunu savunmuştur. Bu parçalayıcı yaklaşımı, dekonstrüktif bir cizim uvarlanısı olarak okumuştur.

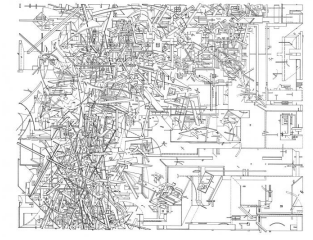

Şekil 1: Libeskind,

Micromegas - Arctic

Flowers, 1979 (Libeskind,

1991: 7)

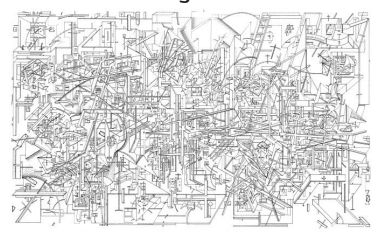

Şekil 2: Libeskind, Micromegas

- Dream Calculus, 1979

(Libeskind, 1991: 8)

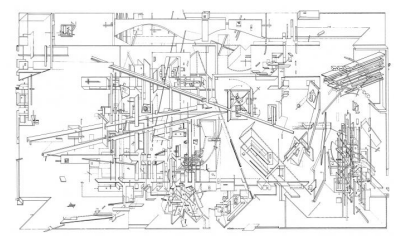

Şekil 3: Libeskind, Micromegas - The Garden, 1979 (Libeskind, 1991: 10) 
Micromegas'ta kullanılan dışavurum üslubu, Libeskind'in o tarihten sonraki tüm projelerinde okunur. Özetle bu iki boyutlu anlatım çalışmalarında kullandığı veriler, mimarın biçim diline dönüşmüştür. Tasarımcının, neredeyse tüm yapılarının ortak özelliği kaotik, kırık çizgisel kütleler veya hacimler kullanmasıdır. Libeskind biçime yönelik sorgulama ve çözümlemelerinde, bilişsel ve duyuşsal birikimlerinde hazır olarak bulunan verilerden etkilenmiştir.

Bu çalışmada analizi gerçekleşen Berlin Yahudi Müzesi Binası projesi bir yarışma sonucu tasarımcısına teslim edilmiştir. Libeskind, inşa edilecek yapıda, Berlin ile Berlin'de yaşayan Musevi vatandaşlar arasında yaşanan tarihsel ilişkiye değinmeyi amaçlamıştır.

Çalışma, temel araştırma olarak Berlin Yahudi Müzesinin ortaya çıkışında, anlamsal-işlevsel-biçimsel sorgulama ve çözümleme ilişkilerini ortaya çıkarmayı hedeflemiştir. Bu amaçla, mimarın anlamsal, işlevsel ve biçimsel kararları ayrı başlıklar halinde değil; her bir öğenin birbirini her an etkilemesi sebebiyle birlikte incelenmiştir. Bu sorgulama ve çözümleme işlemleri, döngüsel sistem sonucu ortaya çıkan eskiz çizimleri ve özetlenmiş şemalar yardımıyla analiz edilmiştir.

\section{Berlin Yahudi Müzesinin Ortaya Çıkışında; Anlamsal-Işlevsel-Biçimsel Sorgulama ve Çözümleme iliş̧kileri}

- Çözümleme 1

\section{Anlama Dair Veri-1}

Elbette ki, mimarın projeye başlaması, ilk adımı atması için majör bir karar bulunur. Copans ve Neumann'a (2003) göre, Libeskind, Yahudi Müzesi projesinin çıkış noktası olarak, Berlin ile Yahudi nüfus arasındaki ilişkiyi belirlemiştir. Bu karar onun zihninde gerçekleştirdiği bir anlamsal sorgulamaçözümleme sonucu açığa çıkmıştır. Bu çözümlemede bilişsel birikiminin kendi de Polonya' da doğmuş ve büyümüş bir Yahudidir- katkısı büyüktür.

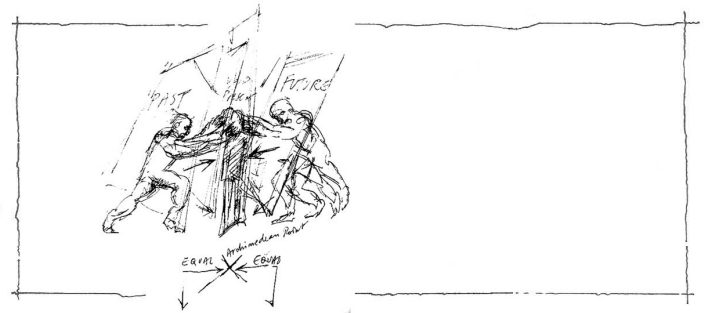

Şekil 4: Libeskind, Anlama Dair Eskizler (Akcan, 2010: 164) 
- Çözümleme 2

\section{Biçime Dair Veri-1}

Zihinde oluşan bu anlamsal verinin türetilmesi, mimarın bu veriyi somutlaştırma intiyacını beraberinde getirmiştir. Libeskind (1997: 96), Berlin ile Yahudi nüfusun arasındaki ilişkiyi, iki çizgisel elemanın birbiriyle olan ilişkisi olarak görmüştür. Seçimin çizgiden yana kullanılması, bu iki verinin süreç olarak devam eden birlikteliğidir. Böylece mimar, anlamsal veriyi biçimleniş için kullanılabilecek bir boyuta dönüştürmüştür.

Libeskind (1997: 32), Between the Lines (Çizgiler Arasında) isimli metninde -Yahudi Müzesi projesine verdiği ad-, projenin iki düşünsel süreç çizgisi hakkında olduğundan ve bu iki çizginin organizasyonu ve ilişkisinden söz etmiştir. Çizgilerden biri Berlin şehrini ve yaşayan Yahudi nüfusun varolupkaybolma durumunu diğeri ise Yahudi nüfusu ve yaşadığı travmaları temsil eder.

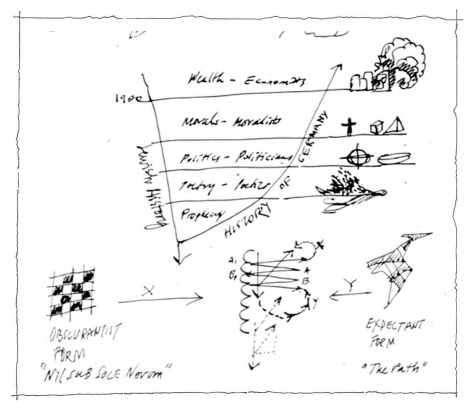

Şekil 5: Libeskind, Berlin ve Yahudi Nüfus Arasında Gelişen Olayları Betimleyen Eskizi (Doğan ve Neressian, 2012: 34)

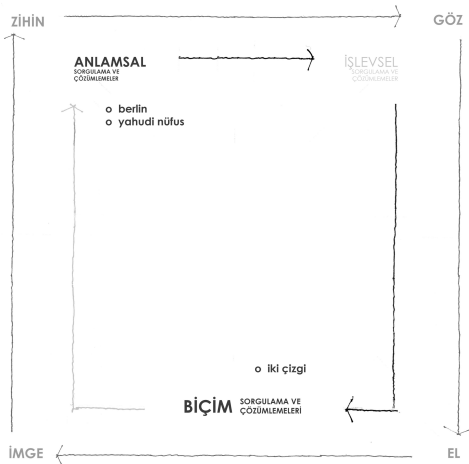

Tablo 1: Çözümleme 1-2 Analiz Diyagramı: Anlamsal verilerin, doğrudan biçimsel sorgulamaçözümlemelere dönüşümü 
- Çözümleme 3

\section{Anlama Dair Veri-2}

Libeskind, Berlin ve Yahudi nüfus arasında süregelen ilişkiyi, inişli çıkışlı bir süreç olarak görmüştür. Bunun nedeni, Yahudi nüfusun yaşadığı acılı dönemler ve şehirden koparılışları, var olma ve yok olma durumlarıdır. Yahudi nüfusun, şehirde hayalet olarak bulunuşu yani boş bir aidiyet ile hayatlarını sürdürmesi ile Berlin'in -Alman Devletinin- kırılarak değişen yapısı ve bu hayatları parçalayıp, bölmesi, mimarın bir sonraki anlamsal verileri olarak ortaya çıkar.

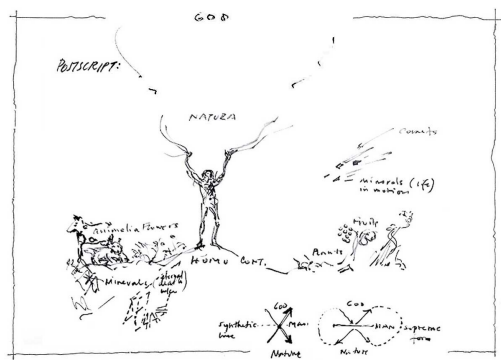

Şekil 6: Libeskind, Anlama Dair Eskizler (Akcan, 2010: 165)

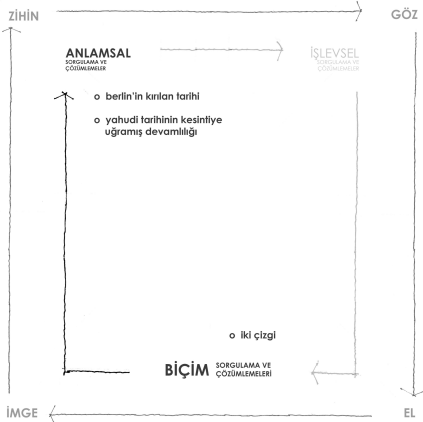

Tablo 2: Çözümleme 3 Analiz Diyagramı: Biçimsel verilerin, tekrar anlamsal sorgulamaçözümlemelere dönüşümü

- Çözümleme 4

Biçime Dair Veri-2

Ortaya çıkan yeni anlamsal veriler somutlaşır ve yeni bilgiler türetir. Yahudi nüfus ile ilişkilendirilen anlamsal veri yani ilk çizgi, düz bir aksta fakat koparılmış parçalardan, Berlin ile ilişkilendirilen diğer çizgi ise zikzak fakat 
devamlı bir yapıdan oluşur. Çizgiler, kimi alanlarda kesişir, kimi yerde ise yüzlerini bambaşka yönlere dönerler. Bir önceki aşamada ortaya çıkan anlamsal veriler, yapılan sorgulama ve çözümleme işlemleri sonucunda bu biçimleniş kararları olarak somutlaşmışlardır.

- Çözümleme 5

\section{Ekstra Veri-1}

Bu biçim sorgulama-çözümleme işlemi gerçekleşirken, Libeskind'in biçimsel üslubu da devreye girerek biçimlenişi etkiler. Mimar Micromegas ve Chamber Works projelerinde kaleme aldığı biçimleniş üslubunun etkilerini bilinçli veya bilinç dışı Berlin Yahudi Müzesi projesine dâhil eder. Bu işlemler, görsel düşünme sürecinin duyuşsal-bilişsel birikimi kullanma aşamasının sonucudur.

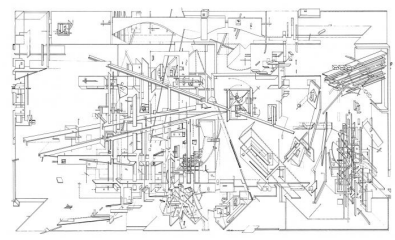

Şekil 7: Libeskind, Micromegas

- The Garden, 1979 (Libeskind, 1997: 10)

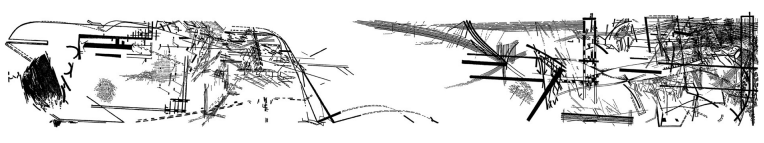

Şekil 8: Libeskind, Chamber Works X-V, 1983

(Studio Daniel Libeskind, 2011)

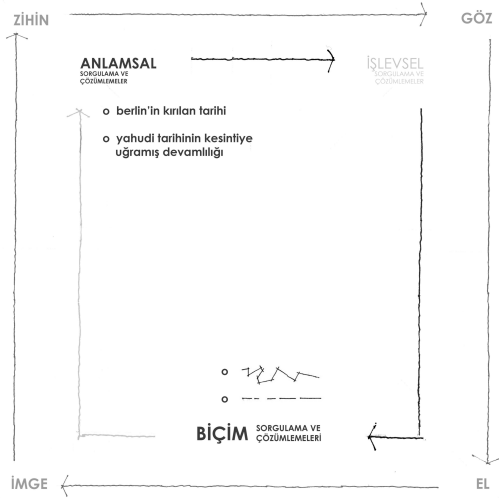

Tablo 3: Çözümleme 4-5 Analiz Diyagramı: Yeni anlamsal verilerin, tekrar biçimsel veri olarak somutlaşması 
- Çözümleme 6

İşleve Dair Veri-1

Anlamsal-biçimsel sorgulamalar ve çözümlemeler sonucunda ortaya çıkan, biri düz-kopuk, diğeri kırık iki çizgisel eleman bu aşamada işleve dair bir sorgulama çözümleme işlemine tabi tutulur. Kullanılacak bu iki çizgi, yapısal elemanlara dönüşerek, müze binası intiyacını karşılayacak işlevleri kazanır. $\mathrm{Bu}$ işlevler; bir çizginin içerisinde dolaşılabilecek bir hacim, diğerinin ise geçiş sağlayacak bir koridor olarak görev yapması kurgusudur.

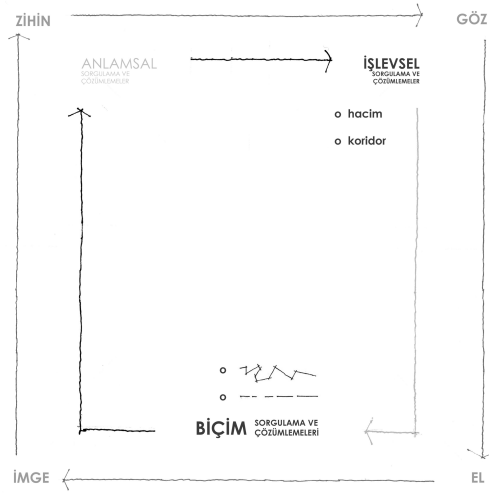

Tablo 4:Çözümleme6 AnalizDiyagramı:Yenibiçimselverilerin, işlevselsorgulama-çözümlemelere dönüşümü

- Çözümleme 7

Biçime Dair Veri-3

Hacim ve koridor olacak şekilde görevlerini edinen iki çizgisel elemanın, bu işlevsel gereksinimleri nasıl karşılayacakları, tekrar bir biçim sorgulamaçözümleme işleminden sonra ortaya çıkacaktır. Bu aşamada, kırık çizgi içerisinde sergilerin bulunduğu hacim, düz çizgi ise içinde boşluklar -kopmalar- bulunan koridor işlevlerini üstlenir. Düz kopuk çizgi belirli noktalardan, kırık çizgi tarafından parçalanacak, bölünecek ve bu noktalarda boşluklar kullanılacaktır. 


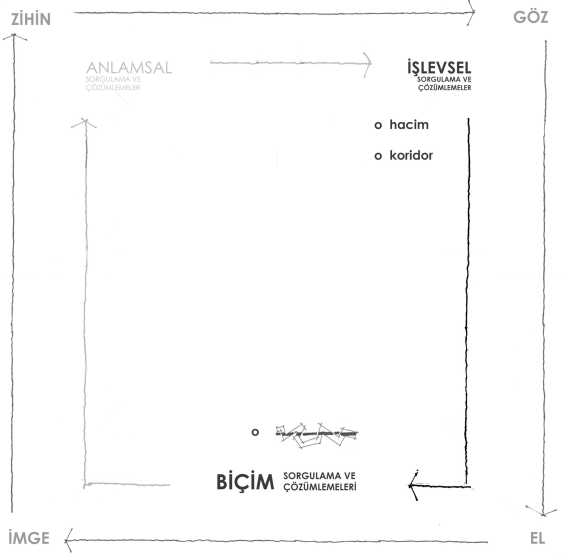

Tablo 5: Çözümleme 7 Analiz Diyagramı: Işslevsel verilerin, tekrar biçimsel kurgulara dönüşümü

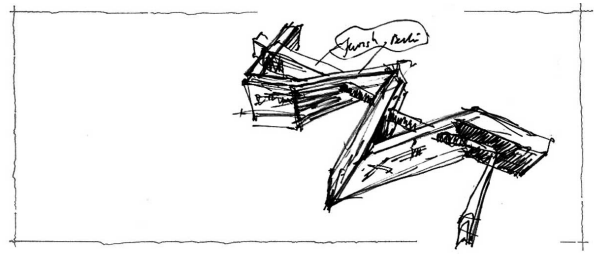

Şekil 9: Libeskind, iki Çizgisel Eleman Arasındaki iliş̧kiyi Betimleyen Eskiz (Doğan ve Neressian, 2012: 37)

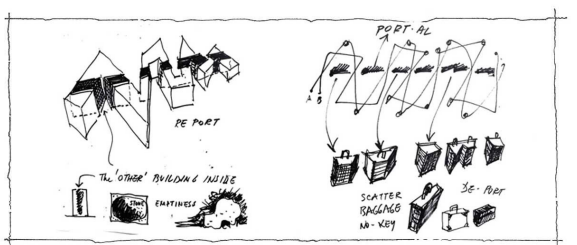

Şekil 10: Libeskind, iki Çizgisel Eleman Arasındaki ilişskiyi Betimleyen Yaratıcı Eskiz (Akcan, 2010: 166)

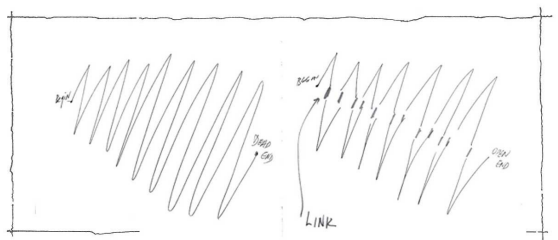

Şekil 11: Libeskind, iki Çizgisel Eleman Arasındaki Ilişkiyi Betimleyen Araştırmacı Eskiz (Akcan, 2010: 165)

Libeskind, yapının araziye oturumunda yine sembolik etmenlerden destek alır. Davut yıldızının köşelerini, şehrin Yahudi tarihi için önem teşkil eden noktalarına denk düşürür ve inşa edeceği müze yapısını bu kriterlere göre belirler. 


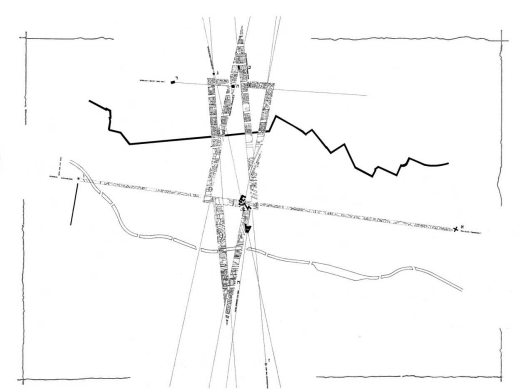

Şekil 12: Libeskind, Davut Yıldızı-Şehir Planı Etkileşim Diagramı (Doğan ve Neressian, 2012: 37)

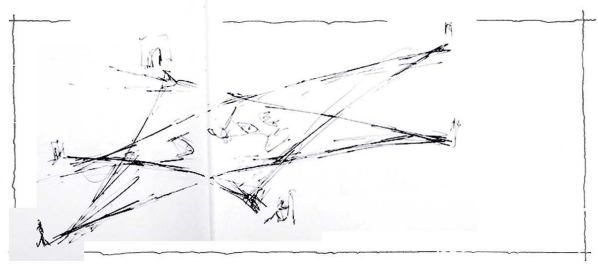

Şekil 13: Libeskind, Davut Yıldızı-Kritik Yapılar, Olaylar Diagramı (Akcan, 2010: 166)

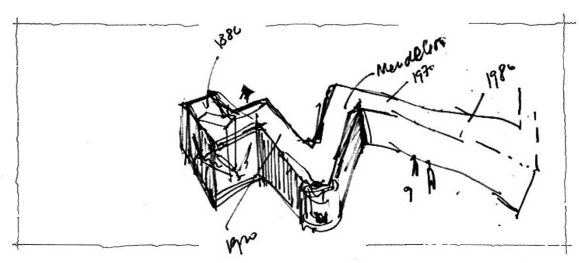

Şekil 14: Libeskind, Sergi Hacminde, Kronolojik Sıraya Göre Biçimlenecek Elemanların Kurgu Eskizi (Doğan ve Neressian, 2012: 37)

Libeskind, tasarımın ana kararlarını belirlemenin ardından, ikincil gereksinimler üzerine sorgulama ve çözümleme eylemlerini gerçekleştirir.

- Çözümleme 8

Anlama Dair Veri-3

Copans ve Neumann (2003)'a göre, Libeskind, Almanya'da yaşayan Yahudi nüfusun yaşadığı acı dolu olay ve durumlar için ekstra bir kurguya gitmiştir. Mimar, bahsi geçen olay ve durumları; süreklilik, sürgün ve soykırım olarak belirler. Süreklilik, Yahudi nüfusun Almanya'daki varlığı; sürgün bu nüfusun yuvalarından sürülüşü; soykırım ise nüfusun katledilmesini açılar. Libeskind, bu soyut kavramlardan yola çıkarak anlama dair sorgulama ve çözümlemelerini gerçekleştirir.

- Çözümleme 9

Biçime Dair Veri-4

Anlamsal sorgulama-çözümlemelerle üzerlerine görevler yüklenen 
süreklilik, sürgün ve soykırım kavramları, projenin ana kararında olduğu üzere çizgisel elemanlar olarak ortaya çıkarlar. Birbirleriyle kesişir fakat farklı yönleri işaret ederler.

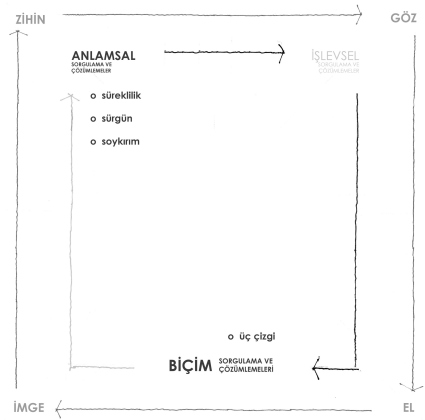

Tablo 6: Çözümleme 8-9 Analiz Diyagramı: İkincil öneme sahip anlamsal verilerin, doğrudan biçimsel verilere dönüşümü

- Çözümleme 10

İşleve Dair Veri-2

Süreklilik, sürgün ve soykırım kavramları, mimarın gerçekleştirdiği görsel düşünme ve görsel anlatım ilişkisi ardından, yapısal görevler edinerek somutlaşır. Libeskind, sürekliliği düz bir koridor olarak -ana kararda olduğu gibi düz fakat kopuk koridorun izdüşümde oluşturulur-, sürgün ve soykırımı ise devamı olmayan -sonlanan- hacimler olarak görevlendirir. Barok yapı ile yeni yapıyı bağlayan geçiş, süreklilik koridoru ile gerçekleştirilir.

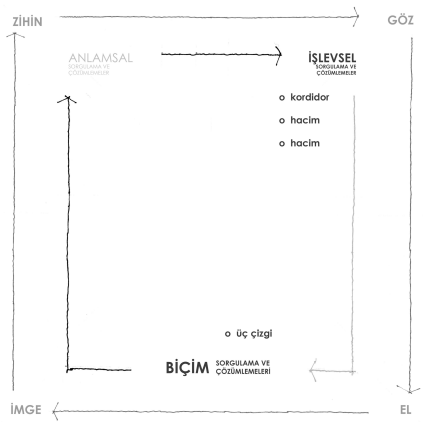

Tablo 7: Çözümleme 10 Analiz Diyagramı: Biçimsel verilerin, yeniden işlevsel verilere dönüşümü 


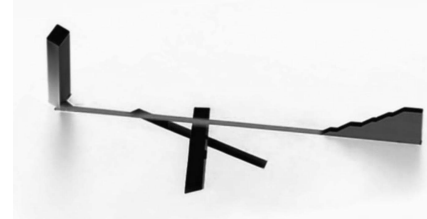

Şekil 15: Süreklilik, sürgün ve soykırım kavramları - koridor ve hacim ilişkileri (Copans ve Neumann, 2003)

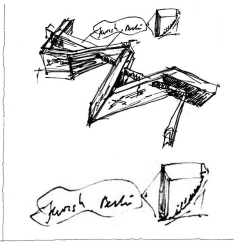

Şekil 16: Libeskind, Barok Yapıyla Yeni Yapının Işleve Dair Geçiş Hacmi Eskizi (Doğan ve Neressian, 2012: 37)

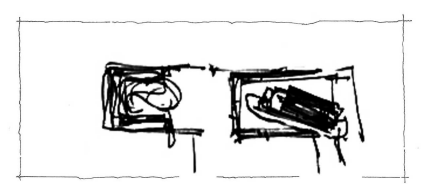

Şekil 17: Libeskind, Barok Yapıyla Yeni Yapının Işsleve Dair Dolaşım Kurgusu Eskizi (Doğan ve Neressian, 2012: 37)

\section{- Çözümleme 11}

\section{Anlama Dair Veri-4}

Libeskind, koridor (süreklilik) ve diğer iki hacmin (sürgün, soykırım), anlamlarını kuvvetlendirmek üzere, bu elemanları bir süreç dâhilinde işletir. Koridorun sonunda, süreklilik kavramını yaşatmak ve Yahudi mevcudiyetini üst bir seviyeye taşımak; sürgün sürecini statikleştirmek, kaçışı olmayan bir duruma getirmek ve soykırımı ise tek yönlü olarak sonlandırmak, kavramların biçimsel ve işlevsel sorgulama-çözümlemelerinin ardından geldikleri noktalardır.

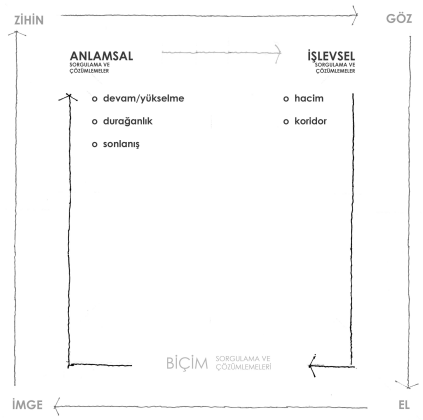

Tablo 8: Çözümleme 11 Analiz Diyagramı: Işslevsel verilerin, yeniden anlama dair nitelikler kazanması 
Libeskind'in, zihin-göz-el-imge arasında gerçekleşen döngüsel paylaşımlar sonucu ortaya çıkan anlam, işlev ve biçime dair ana tasarım kararları aşağıdaki eskizlerle özetlenebilir.

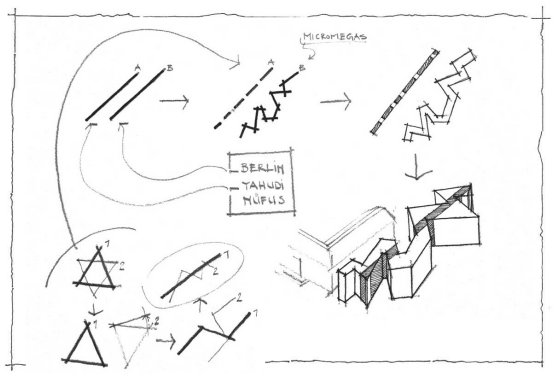

Şekil 18: Berlin (kırık çizgi) ve Yahudi nüfus (düz fakat kopuk çizgi) arasındaki ilişki şeması

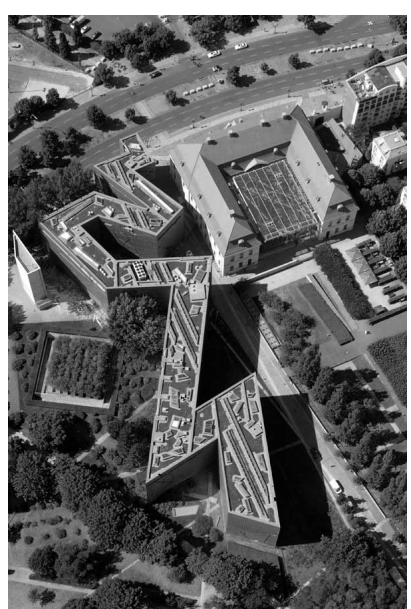

Şekil 19: Kuşbakışı Berlin (kırık çizgi) ve Yahudi nüfus (düz fakat kopuk çizgi) arasındaki ilişki (Studio Daniel Libeskind, 2011)

\section{Sonuç}

Mimari yapı özelinde gerçekleştirilen eskiz analizlerinin sonucunda, tasarlama sürecinde eskiz ile düşünme sonucu ortaya çıkan ve/veya geliştirilen aşamaların; projeye dair anlamsal, işlevsel ve biçimsel sorgulama-çözümlemelerle sonuçlandığı görülmüştür. Eskiz çalışmaları ile salt, somut işlevsel veya biçimsel değil, soyut bilgileri içeren anlama dair sorgulamalar ve çözümlemelerin de gerçekleştirildiği izlenmiştir. Anlam-işlev-biçime dair bu analizlerin çizgisel -herhangi bir sıraya bağlıişlemediği; eş zamanlı ve birbiri arası bilgi aktarımlarda döngüsel sistematik ile çalıştığı gözlemlenmiştir.

Bu değerlendirmeler ışı̆̆ında eskiz çalışmalarının;

- Zihin-göz-el-imge arasındaki sürekli ilişki sonucunda, genel başlıklarıyla; anlamsal, işlevsel ve biçimsel verilerin üretildiği ve geliştirildiği,

- Anlamsal, işlevsel veya biçimsel her tür tasarım verisini oluşturmak ve geliştirmek için kullanılabilir olduğu, 
- Anlama, işleve veya biçime dair herhangi bir eskizin eş zamanlı olarak birbirini geliştirdiği sonuçlarına varılmıştır.

Gelecekte, bu çalışmanın verilerinden yararlanılarak, tasarım sürecinde eskiz çalışmalarıyla, tasarım bilgisi oluşturma ve geliştirme eylemlerini, hiçbir tasarımcının bireysel niteliklerinden ödün verilmeksizin, tümünün düşünsel sistematikleriyle dâhil olabileceği bir düşünsel formülasyon önerisi getirilmesi hedeflenmektedir. 


\section{Kaynakça}

Akin, O. (1990). Necessary Conditions for Design Expertise and Creativity. Design Studies 11, 107-113

Brooker, G. ve Stone, S. (2011). İç Mekân Tasarımı Nedir? İstanbul: Yapı Endüstri Merkezi Yayınları.

Copans, R. ve Neumann, S. (Yapımcı, Senarist, Yönetmen). (2003). Baukunst: Das Jüdiche Museum in Berlin. France;-.

Gero, J. S. (1999). Constructive memory in Design Thinking. Design Thinking Research Symposium: Design Representation, 29-35.

Goldsmith, G. (1994). On Visual Design Thinking: The Vis Kids of Architecture. Design Studies 15, 158-174

Inceoğlu, N. (2012). Eskizler, Çizerek Düşünme Düşünerek Çizme. İstanbul: Nemli Yayıncılık.

Laseau, P. (2001). Graphic Thinking for Architects \& Designers. Canada: John Wiley \& Sons, Inc.

Lawson, B. (1990). How Designers Think?. Butterworth Architecture, Oxford UK

Libeskind, D. (1991). Daniel Libeskind: Countersign. London: Academy Editions.

Libeskind, D. (1997). Radix-Matrix: Architecture and Writings. Munich, New York: Prestel.

Pallasmaa, J. (2009). The Thinking Hand Existential and Embodied Wisdom in Architecture. West Sussex, UK: John Wiley \& Sons Ltd.

Steadman, P. (1972). The Evolution of Design: Biological Analogy in Architecture and the Applied Arts. Cambridge University Press, Cambridge UK

Young, J. E. (2000). Daniel Libeskind's Jewish Museum in Berlin: The Uncanny Arts of Memorial Architecture. Jewish Social Studies, 6.2, 1-23.

İnternet Kaynakları

Internet: Studio Daniel Libeskind. (2011). http://daniel-libeskind.com/projects/ chamber-works/drawings adresinden 4 Kasım 2012 tarihinde alınmıştır.

Internet: Wilks. http://sfac.wustl.edu adresinden 10 Eylül 2012 tarihinde alınmıştır. 


\section{Görsel Kaynakları}

Akcan, E. (2010). Apology and Triumph: Memory Transference, Erasure and Rereading of the Berlin Jewish Museum. New German Critique, 37.2, 153-179.

Copans, R. ve Neumann, S. (Yapımcı, Senarist, Yönetmen). (2003). Baukunst: Das Jüdiche Museum in Berlin. France.

Doğan, F. ve Neressian, N. J. (2012). Conceptual Diagrams in Creative Architectural Practice: The Case of Daniel Libeskind's Jewish Museum. Architectural Research Quarterly, Cambridge University Press, 16.1, 15-27.

Libeskind, D. (1991). Daniel Libeskind: Countersign. London: Academy Editions.

Studio Daniel Libeskind. (2011). http://daniel-libeskind.com/projects/chamberworks/drawings adresinden 4 Kasım 2012 tarihinde alınmıştır. 